\title{
Production in forage sorghum intercropped with grasses and pigeon pea at crop cutting ${ }^{1}$
}

\author{
Produção de sorgo forrageiro consorciado com gramíneas e guandu-anão no corte da \\ safra
}

\author{
Sanderley Simões da Cruz ${ }^{2 *}$, Marcelo Andreotti ${ }^{3}$, Isabô Melina Pascoaloto ${ }^{4}$, Gilmar Cotrin de Lima ${ }^{5}$ and \\ Caroline de Aquino Soares ${ }^{6}$
}

\begin{abstract}
Due to the need to implement sustainable systems of high productivity for farming, the aim of this study was to evaluate the agronomic characteristics of forage sorghum (Sorghum bicolor (L.) Moench) intercropped with Urochloa brizantha, Megathyrsus maximum and/or pigeon pea in a non-irrigated area of a low-altitude region of the Cerrado. A randomised block design was used, of plots split over time with six treatments and four replications over two agricultural years. The treatments were (I) monocropped forage sorghum, and forage sorghum intercropped with (II) U. brizantha, (III) M. maximum, (IV) U. brizantha and pigeon pea, (V) M. maximum and pigeon pea, and (VI) pigeon pea. The following were evaluated in the sorghum and its respective intercrops: plant height, stem diameter, stand and productivity. Intercropping sorghum with M. maximum reduced fresh and dry matter production in the sorghum, albeit with no significant effect on total dry matter production for the intercrop. Sorghum intercropped with M. maximum gave a higher percentage of panicles than the other intercropped systems.
\end{abstract}

Key words: Cajanus cajan. Megathyrsus maximum. Urochloa brizantha.

RESUMO - Devido à necessidade de implantação de sistemas sustentáveis e de alta produtividade na agropecuária, objetivouse avaliar as características agronômicas do sorgo (Sorghum bicolor (L.) Moench) forrageiro consorciado com o Urochloa brizantha, Megathyrsus maximum e/ou guandu-anão em região de Cerrado de baixa altitude, em área não irrigada. Utilizou-se o delineamento em blocos casualizados, em parcela subdividida no tempo com seis tratamentos e quatro repetições durante dois anos agrícolas. Os tratamentos utilizados foram (I) sorgo forrageiro em monocultivo e consorciado com: (II) U. brizantha; (III) M. maximum; (IV) U. brizantha e guandu-anão; (V) M. maximum e guandu-anão; e (VI) guandu-anão. Foram avaliadas a altura de plantas, o diâmetro do colmo, o estande de plantas e a produtividade do sorgo e seus respectivos consórcios. Os consórcios de sorgo com M. maximum reduziram a produtividade de massa verde e seca do sorgo, entretanto sem efeito significativo na produtividade de massa seca total do consórcio. O sorgo consorciado com M. maximum proporcionou maior porcentagem de panícula que os demais consórcios.

Palavras-chave: Cajanus cajan. Megathyrsus maximum. Urochloa brizantha.

\footnotetext{
DOI: $10.5935 / 1806-6690.20200031$

*Author for correspondence

Received for publication 18/10/2016; approved on 13/02/2020

'Parte da Tese de Doutorado do primeiro autor, apresentado ao Curso de Pós-Graduação em Agronomia, Faculdade de Engenharia, Universidade Estadual Paulista "Júlio de Mesquita Filho"/UNESP

${ }_{2}^{2}$ Instituto Federal de Educação, Ciência e Tecnologia do Pará/IFPA, Campus Marabá Rural, Marabá-PA, Brasil, ssdacruz@yahoo.com.br (ORCID ID 0000-0001-5225-8466)

"Departamento de Fitossanidade, Engenharia Rural e Solos, Faculdade de Engenharia, Universidade Estadual Paulista "Júlio de Mesquita Filho"/ UNESP, Ilha Solteira-SP, Brasil, marcelo.andreotti@ unesp.br (ORCID ID 0000-0001-6857-9926)

${ }^{4}$ Doutoranda no Programa de Agricultura, Departamento de Produção e Melhoramento Vegetal, Faculdade de Ciências Agronômicas, Universidade Estadual Paulista “Júlio de Mesquita Filho"/UNESP, Botucatu-SP, Brasil, isabomelina @ gmail.com (ORCID ID 0000-0003-4040-1135)

${ }^{5}$ Doutorando no Programa de Pós-graduação em Zootecnia, Faculdade de Ciências Agrárias e Veterinárias, Universidade Estadual Paulista "Júlio de Mesquita Filho"/UNESP, Jaboticabal-SP, Brasil, gilmarcotrinlima@ gmail.com (ORCID ID 0000-0001-8746-2029)

${ }^{6}$ Tecnóloga de Alimentos, Mestre em Ciência Animal, Instituto Federal de Educação, Ciência e Tecnologia do Pará/IFPA, Marabá-PA, Brasil, carolaquino4@yahoo.com.br (ORCID ID 0000-0002-9480-6720)
} 


\section{INTRODUCTION}

Intercropping grain crops with grasses is the basis of the Integrated Farming Production System (IFPS), and seeks to improve benefits for the soil, plants, and animals. This type of integration is advantageous, as it benefits agricultural and livestock activities, offering gains to the producer. Such systems have been the object of study in various regions of the world to promote technological innovation in agricultural activities (CARVALHO et al., 2010).

For Lanzanova et al. (2007), many producers are afraid to adopt this system due to a lack of knowledge of the correct establishment and management of crops when grown in an intercropped system. According to Miranda et al. (2010), among the various options, the use of sorghum for forage production has taken on an increasingly important role in recent years, both in Brazil and worldwide, as its resistance to adverse environmental factors is well known compared to maize, which is the most popular crop for silage production. Sorghum also offers high dry-matter productivity per area, a good fermentation pattern, and high nutritional value, both in the production of silage and supplying fresh feed to ruminants.

The regrowth ability of sorghum is another great advantage in intensive production systems, as after harvesting the grain or shoots, a new harvest is possible without the need to replant the crop. It is also possible to manage crop regrowth for grazing in IFPS programs, or to use the straw produced from plant regeneration as ground cover in an on-going no-till system (FOLONI et al., 2008).

Several studies have demonstrated the technical viability of intercropping forages with cereals (CARVALHO et al., 2011), however, variations in the results from different regions of Brazil highlight the importance of regionalised research. It is therefore necessary to understand the interactions and interference that occur when intercropping sorghum with forage grasses, and identify which species best adapts to intercropping in low-altitude regions of the Cerrado.

The aim of this study was to evaluate the agronomic characteristics of forage sorghum as a monocrop and intercropped with $U$. brizantha 'Marandu', M. maximum 'Mombasa' and/or pigeon pea, in an integrated farming production system in a low-altitude region of the Cerrado, over two agricultural years.

\section{MATERIAL AND METHODS}

The experiment was conducted in a nonirrigated area of the Plant Production Sector at the
Teaching, Research and Extension Farm (FEPE) of the Ilha Solteira School of Engineering (FEIS/UNESP), in Selvíria, Mato Grosso do Sul (MS) $\left(20^{\circ} 18^{\prime} \mathrm{S}\right.$ and $51^{\circ} 22^{\prime} \mathrm{W}$, altitude $370 \mathrm{~m}$ ). According to the Köppen classification, the climate in the region is type Aw, humid tropical with a rainy season during the summer and dry season during the winter. The rainfall data, and the maximum, minimum and mean temperatures (Figure 1) were recorded daily by an automatic weather station installed about $500 \mathrm{~m}$ from the experimental area.

The treatments were carried out during the 2013/2014 and 2014/2015 agricultural years, using a randomised block design of plots split over time, with six treatments and four replications, giving a total of 24 plots with a width of $2.92 \mathrm{~m}$ and length of $20 \mathrm{~m}$ total area per plot. The treatments were set up during the first (2013) and second year (2014), on the 8 th and 4 th of November respectively. In the second year (2014/2015), the experiment was set up in the same area as the plot of the previous year. The treatments under evaluation were (I) monocropped forage sorghum, and forage sorghum intercropped wit: (II) $U$. brizantha 'Marandu', (III) $M$. maximum 'Mombasa', (IV) U. brizantha 'Marandu' and pigeon pea, (V) M. maximum 'Mombasa' and pigeon pea, and (VI) pigeon pea.

The soil of the experimental area was classified as a typical clayey Red Latosol (EMPRESA BRASILEIRA DE PESQUISA AGROPECUÁRIA, 2013). To characterise the soil before setting up the experiment (8 Nov 2013), an analysis of the chemical quality was carried out as per the methodology proposed by Raij et al. (2001), where the following values were found in the 0 to $0.10 \mathrm{~m}$ layer: resin $\mathrm{P}\left(\mathrm{mg} \mathrm{dm}^{-3}\right)$ of 62 ; $\mathrm{OM}\left(\mathrm{g} \mathrm{dm}^{-3}\right)$ of $21 ; \mathrm{pH}$ in $\mathrm{CaCl}_{2}$ of 4.8: $\mathrm{K}, \mathrm{Ca}, \mathrm{Mg}, \mathrm{H}+\mathrm{Al}$ and $\mathrm{Al}\left(\mathrm{mmol}_{\mathrm{c}} \mathrm{dm}^{-3}\right)$ of $1.6,12$, 10,38 and 3 respectively; S-SO 4 of $5^{\mathrm{c}} \mathrm{mg} \mathrm{dm}^{-3}$; V\% of 38; and $\mathrm{Cu}, \mathrm{Fe}, \mathrm{Mn}$ and $\mathrm{Zn}$ of 2.6, 26, 21 and $1.2 \mathrm{mg} \mathrm{dm}^{-3}$ respectively. In the 0.10 to $0.20 \mathrm{~m}$ layer, the values were: resin $\mathrm{P}\left(\mathrm{mg} \mathrm{dm}^{-3}\right)$ of 17 ; $\mathrm{OM}\left(\mathrm{g} \mathrm{dm}^{-3}\right)$ of 16 ; $\mathrm{pH}$ in $\mathrm{CaCl}_{2}$ of 4.4; K, Ca, Mg, $\mathrm{H}+\mathrm{Al}$ and $\mathrm{Al}\left(\mathrm{mmol}_{\mathrm{c}} \mathrm{dm}^{-3}\right)$ of $1,7,6,47$ and 8 respectively; S-SO4 of $15 \mathrm{mg} \mathrm{dm}^{-3}$ and V\% of 23.

The species under study were sown in rows $0.45 \mathrm{~m}$ apart, with the sorghum and forage grasses sown in the same row and the pigeon pea between the rows. The sorghum was sown mechanically at a depth of approximately $0.05 \mathrm{~m}$ and 15 seeds per metre by means of a planter-fertiliser with a rod-like furrowing mechanism (blade) for direct planting. The forage grasses were sown together with the sorghum, mixing the seeds with the fertiliser immediately prior to planting, with the aim of delaying emergence and reducing the probable competition between species during the initial period of development. For the first year, $13.3 \mathrm{~kg} \mathrm{ha}^{-1}$ marandu grass seed $\left(\mathrm{PLS}=36 \%\right.$ ) and $14.4 \mathrm{~kg} \mathrm{ha}^{-1}$ mombasa grass 
Figure 1 - Climate data shown for intervals of ten days, from November 2013 to February 2014 and November 2014 to March 2015 , collected at the FEPE weather station. Selvíria MS

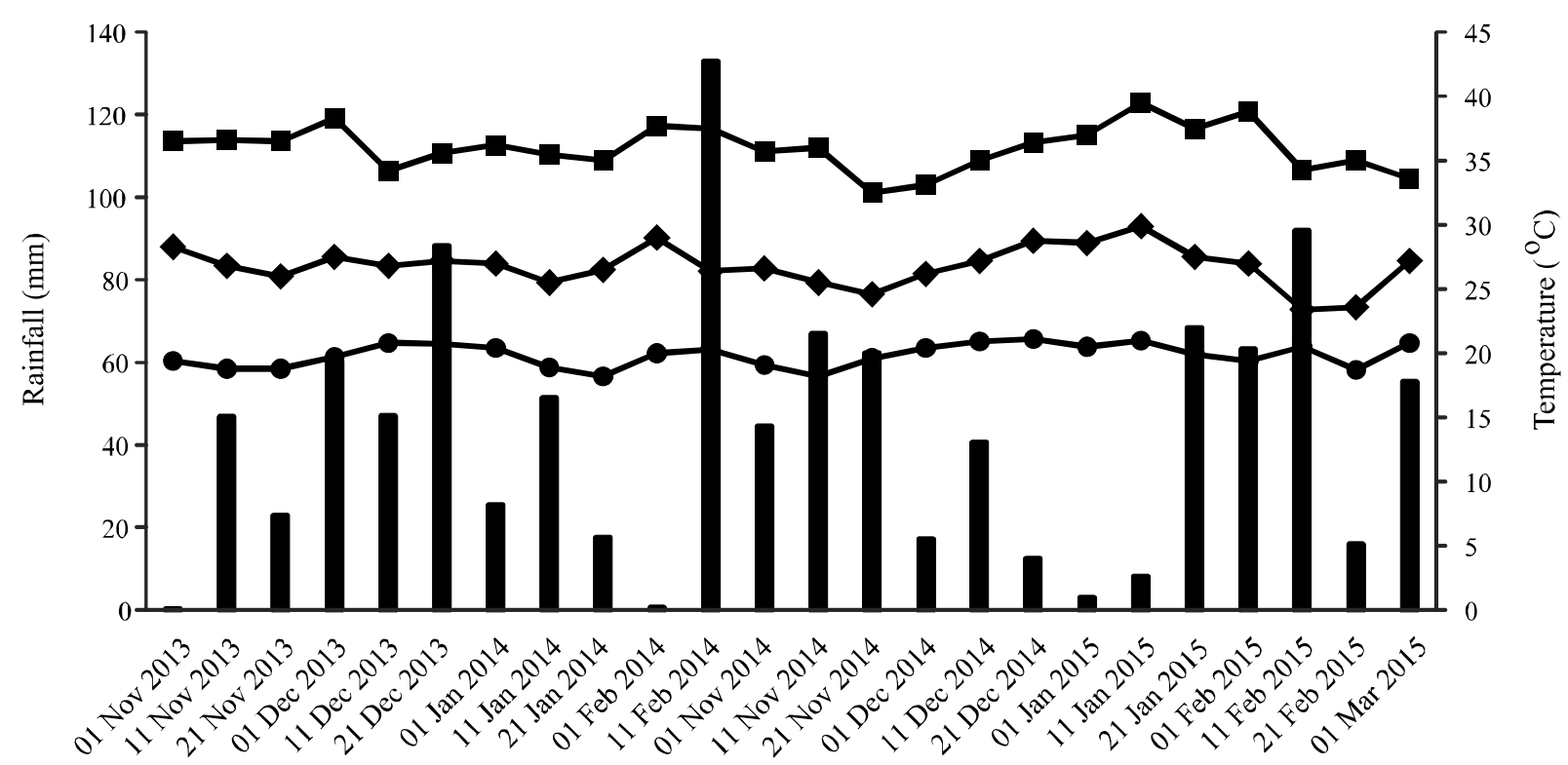

Experimental period in intervals of 10 days

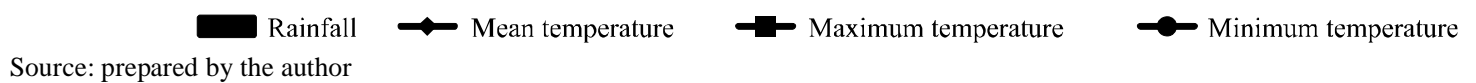

seed $(\mathrm{PLS}=25 \%)$ were used, and in the second year $9.6 \mathrm{~kg} \mathrm{ha}^{-1}$ marandu grass (PLS $=50 \%$ ) and $10.3 \mathrm{~kg} \mathrm{ha}^{-1}$ mombasa grass (PLS $=35 \%$ ). The pigeon pea was sown immediately after the sorghum/ forage grasses, at a depth of $0.06 \mathrm{~m}$ and 20 seeds per metre, using a different planterfertiliser.

For each agricultural year (2013/2014 and 2014/2015), $300 \mathrm{~kg} \mathrm{ha}^{-1}$ formula 08-28-16 were applied when sowing, with $120 \mathrm{~kg} \mathrm{ha}^{-1} \mathrm{~N}$ (ammonium sulphate) and $50 \mathrm{~kg} \mathrm{ha}^{-1} \mathrm{~K}_{2} \mathrm{O}$ (potassium chloride) applied manually per plot as cover (stage V6 of the sorghum).

The sorghum was harvested for silage 105 days after sowing (DAS) (21 Feb 2014) in the first year of the experiment, and 124 DAS (7 Mar 2015) in the second year, when the grain in the panicle appeared to be at the farinaceous stage. During the interval between cutting in the first year and sowing in the second year, regrowth management of the sorghum and forage grasses took place, with subsequent desiccation for the no-till system.

When harvesting the plants in each treatment, the following attributes were evaluated in the forage sorghum: plant height (from the collar to the end of the panicle); basal stem diameter (determined by calliper at the second internode from the collar), measured in ten randomly chosen plants per plot; final stand (counting the total number of plants in the three central rows, three metres in length). Fresh matter production in the sorghum, grasses and pigeon pea was evaluated by collecting all the material found in $1 \mathrm{~m}^{2}$ (3 replications/plot), which was cut $0.30 \mathrm{~m}$ from the ground and weighed on a digital balance; the sorghum was then separated into stem, leaves and panicle for the various parts to be quantified.

After weighing the fresh matter, sub-samples were removed and again weighed to determine the dry matter production of the sorghum, forage grasses and pigeon pea, as well as the various parts of the sorghum. For this, the material was placed in a forced air circulation oven at $65^{\circ} \mathrm{C}$ for 72 hours.

The results were subjected to analysis of variance, considering the treatments, the years, and the interaction between these factors as the sources of variation, with the interaction broken down or not depending on its significance by F-test. Tukey's test at 5\% probability was used to compare the mean values employing the SISVAR software (FERREIRA, 2011).

\section{RESULTS AND DISCUSSION}

Table 1 shows the results for mean height, basal stem diameter and stand in the sorghum plants at the time of the first cut. Significance was found $(\mathrm{P}<0.05)$ between 
all the attributes under evaluation for the intercropped systems, the years, and their interaction.

In analysing the breakdown between years for each treatment, the greater plant height seen during the first year (Table 1) can be attributed to the smaller stand, and therefore, to less intraspecific competition, with more light intercepted by the leaves and a larger individual area for exploiting the soil. This was mainly due to the low rainfall that occurred immediately after sowing (Figure 1), together with the higher temperatures during the first year and a higher rate of photosynthesis.

However, Rabelo et al. (2012), studying sowing strategies and fertilisation with NPK in sorghum, found that plants grown at a population density of 12 plants per metre were taller, due to the intraspecific competition in the search for light increasing the length of the internodes and, consequently, of the plant. According to May et al. (2012a), competition for light is one of the modes of interference that most alters plant growth, as it limits the main source for energy absorption to the basic processes of recruiting elements and producing each substance involved in the growth of the plant.

In breaking down treatment interaction within each year (Table 2), the sorghum plants intercropped with marandu grass and pigeon pea $(2.58 \mathrm{~m})$, and as a single crop $(2.28 \mathrm{~m})$, presented the greatest heights during the first and second year respectively.
Studying the characteristics of four sorghum genotypes for silage production, Botelho et al. (2011) found heights of between 2.10 to $2.35 \mathrm{~m}$, values close to those found in the present study. Chiesa et al. (2008) also obtained heights of 1.72, 2.16 and $2.52 \mathrm{~m}$ in the sorghum hybrids AG2005E, AG60298 and BR101 respectively.

Albuquerque et al. (2011), evaluating forage sorghum cultivars at three different spacings over two agricultural years under the climate conditions of the semi-arid region of Minas Gerais, where the first year was considered rainy $(519 \mathrm{~mm})$ and the second year dry $(219 \mathrm{~mm})$, found that, irrespective of the attributes under analysis, during the first agricultural year, plant height was greater compared to the second year, with a mean of 3.34 and $2.19 \mathrm{~m}$ respectively.

Benício et al. (2011) however, studied the efficiency of different cultivars of $M$. maximum intercropped with sorghum under sources of phosphorus and found that at the end of the first year the height of the sorghum was greater when grown together with massai grass, due to its smaller size (around $0.70 \mathrm{~m}$ ) and, therefore, to the lower competition for light between the sorghum and the grass. In general, the intercropped systems with forage grasses tested here did not alter the growth of the sorghum plants, due to their high competitive ability, being able to achieve the same performance as under single cultivation, according to reports by Kluthcouski and Aidar (2003) with data similar to those found in this experiment.

Table 1 - Mean values, Tukey's test and P-value (Anova) for height, basal stem diameter and stand, in sorghum intercropped with marandu grass, mombasa grass and/or pigeon pea, under an Integrated Farming Production System in a low-altitude region of Cerrado, at the time of the first cut. Selvíria MS

\begin{tabular}{|c|c|c|c|}
\hline Treatment (Trmt) & Height (m) & Diameter $(\mathrm{cm})$ & Sorghum stand (plants ha-1) \\
\hline Sorghum/Marandu/Pigeon Pea & $2.33 \mathrm{a}$ & $1.9 \mathrm{ab}$ & $260.431 \mathrm{ab}$ \\
\hline Sorghum/Marandu & $2.30 \mathrm{ab}$ & $2.1 \mathrm{a}$ & $257.245 \mathrm{ab}$ \\
\hline Sorghum/Mombasa/Pigeon Pea & $2.10 \mathrm{~b}$ & $1.8 \mathrm{ab}$ & $178.875 \mathrm{~b}$ \\
\hline Sorghum/Mombasa & $2.22 \mathrm{ab}$ & $1.8 \mathrm{ab}$ & $178.389 \mathrm{~b}$ \\
\hline Sorghum/Pigeon Pea & $2.30 \mathrm{ab}$ & $1.7 \mathrm{~b}$ & $303.657 \mathrm{a}$ \\
\hline Single Sorghum & $2.24 \mathrm{ab}$ & $2.0 \mathrm{ab}$ & $256.579 \mathrm{ab}$ \\
\hline $\mathrm{CV}(\%)$ & 5.6 & 6.1 & 22.3 \\
\hline \multicolumn{4}{|c|}{ Year $(Y)$} \\
\hline $2013 / 2014$ & $2.34 \mathrm{a}$ & $1.7 \mathrm{~b}$ & $199.225 \mathrm{~b}$ \\
\hline $2014 / 2015$ & $2.15 \mathrm{~b}$ & $2.1 \mathrm{a}$ & $279.167 \mathrm{a}$ \\
\hline \multicolumn{4}{|c|}{ Anova (P-value) } \\
\hline Trmt & 0.0291 & 0.0273 & 0.0068 \\
\hline $\mathrm{Y}$ & 0.0001 & 0.0000 & 0.0001 \\
\hline Trmt x Y & 0.0015 & 0.0003 & 0.0255 \\
\hline
\end{tabular}

Mean values followed by the same letter in a column do not differ by Tukey's test at $5 \%$ significance $(\mathrm{P}<0.05)$ for treatment, or by F-test $(\mathrm{P}<0.01)$ for year 
Table 2 - Mean values and Tukey's test in the breakdown of the Treatment $\mathrm{x}$ Year interaction for height and basal stem diameter, in sorghum intercropped with marandu grass, mombasa grass and/or pigeon pea, under an Integrated Farming Production System in a low-altitude region of Cerrado, at the time of the first cut. Selvíria MS

\begin{tabular}{ccccc}
\hline \multirow{2}{*}{ Treatment } & \multicolumn{2}{c}{ Height $(\mathrm{m})$} & \multicolumn{2}{c}{ Diameter $(\mathrm{cm})$} \\
\cline { 2 - 5 } & $2013 / 2014$ & $2014 / 2015$ & $2013 / 2014$ & $2014 / 2015$ \\
\hline Sorghum/Marandu/Pigeon Pea & $2.58 \mathrm{aA}$ & $2.05 \mathrm{aB}$ & $1.8 \mathrm{aA}$ & $2.1 \mathrm{abA}$ \\
Sorghum/Marandu & $2.46 \mathrm{abA}$ & $2.13 \mathrm{aB}$ & $1.9 \mathrm{aB}$ & $2.2 \mathrm{aA}$ \\
Sorghum/Mombasa/Pigeon Pea & $2.13 \mathrm{cA}$ & $2.08 \mathrm{aA}$ & $1.5 \mathrm{bB}$ & $2.2 \mathrm{aA}$ \\
Sorghum/Mombasa & $2.25 \mathrm{bcA}$ & $2.19 \mathrm{aA}$ & $1.7 \mathrm{abB}$ & $2.0 \mathrm{abA}$ \\
Sorghum/Pigeon Pea & $2.41 \mathrm{abA}$ & $2.19 \mathrm{aB}$ & $1.8 \mathrm{aA}$ & $1.8 \mathrm{bA}$ \\
Single Sorghum & $2.20 \mathrm{bcA}$ & $2.28 \mathrm{aA}$ & $1.8 \mathrm{aB}$ & $2.1 \mathrm{aA}$ \\
\hline MSD row & & 0.18 & & 0.5 \\
\hline
\end{tabular}

Mean values followed by the same lowercase letter in a column and uppercase letter on a row do not differ by Tukey's test (P<0.05) or by F-test $(\mathrm{P}<0.01)$. MSD: minimum significant difference by Tukey's test

Plant height and stem diameter may be positively correlated with fresh and dry matter production, however they can also show a positive correlation with the percentage of stalks and subsequent lodging, characteristics that are undesirable for efficient forage production (ALBUQUERQUE et al., 2011; MAY et al., 2012b).

For stem diameter (Table 1), and from the breakdown of the interaction between treatments and years (Table 2), it was found that during the second year the sorghum plants presented the greatest diameters and also the largest stands. These results are similar to those obtained by Fernandes et al. (2014), who evaluated the interference of inter-row spacing and plant population on the production of saccarine sorghum for two sowing times, the first season and the off-season, and found a decrease of $1.2 \mathrm{~mm}$ in stem diameter from 80,000 plants ha ${ }^{-1}$. These results corroborate those obtained by May et al. (2012b), who state that an increase in plant population per hectare can result in a reduction in stem diameter.

When evaluating the breakdown of the interaction between treatments for basal stem diameter (Table 2), it was found that sorghum with marandu grass $(1.9 \mathrm{~cm})$, and sorghum with mombasa grass and pigeon pea $(2.2 \mathrm{~cm})$ were the two cropping systems with the largest stem diameters in 2013/2014 and 2014/2015 respectively.

Table 1 also shows that for the final stand of the sorghum plants, sorghum intercropped with mombasa grass $\left(178,389\right.$ plants $\left.\mathrm{ha}^{-1}\right)$, and with mombasa grass and pigeon pea $\left(178,875\right.$ plants $\left.\mathrm{ha}^{-1}\right)$ were the two treatments giving the smallest stands. The small stand in these intercropped systems can be explained by the accelerated growth and tillering of the mombasa grass, which may have contributed to greater competition with the sorghum, thereby reducing the stand.
From the data shown in Table 3, with the breakdown of the interaction between treatments, it appears that during the first year of production the sorghum intercropped with mombasa grass, and with mombasa grass and pigeon pea, were the only treatments showing a significant difference $(\mathrm{P}<0.01)$, since the greater initial competition between the sorghum and the forage grass resulted in a reduction in the stand, aggravated by there being little rainfall shortly after sowing the intercrops (Figure 1). Whereas during the second year of evaluation, for the sorghum intercropped with mombasa grass, and with mombasa grass and pigeon pea, there was an increase of $137 \%$ in the number of sorghum plants, a fact attributed to the greater rainfall distribution during the second year of evaluation, as shown in Figure 1.

Despite the low sorghum stands when intercropped with mombasa grass, and with mombasa grass and pigeon pea, the values are greater than those recommended for forage sorghum, which is between 100 to 150 thousand plants per hectare, nevertheless, it is worth highlighting the need for larger plant populations in intercropped systems due to the effect of competition, when the aim is to produce forage for silage. However, it can be seen in Table 1 that the mombasa grass had a strong competitive effect on the sorghum, showing, under the evaluated conditions of low water availability, the low viability of this type of intercropped system when the aim is to achieve regrowth in the sorghum, since, due to competition with the forage grass after harvesting, there is a significant reduction in sorghum regrowth for the production of silage or grain.

Oliveira et al. (2005), evaluating the characteristics of sorghum cultivars under three doses of nitrogen, found a population ranging from 167 to 213 thousand plants per hectare. Von Pinho et al. (2006) evaluated the behaviour of maize cultivars compared to groups of sorghum cultivars 
Table 3 - Mean values and Tukey's test in the breakdown of the Treatment $x$ Year interaction, for plant stand in sorghum intercropped with marandu grass, mombasa grass and/or pigeon pea, under an Integrated Farming Production System in a low-altitude region of Cerrado, at the time of the first cut. Selvíria MS

\begin{tabular}{|c|c|c|}
\hline \multirow{2}{*}{ Treatment } & \multicolumn{2}{|c|}{ Sorghum stand (plants ha ${ }^{-1}$ ) } \\
\hline & $2013 / 2014$ & $2014 / 2015$ \\
\hline Sorghum/Marandu/Pigeon Pea & $205,861 \mathrm{abB}$ & $315,000 \mathrm{aA}$ \\
\hline Sorghum/Marandu & $240,741 \mathrm{aA}$ & $273,750 \mathrm{aA}$ \\
\hline Sorghum/Mombasa/ Pigeon Pea & $104,000 \mathrm{bB}$ & $253,750 \mathrm{aA}$ \\
\hline Sorghum/Mombasa & $108,027 \mathrm{bB}$ & $248,750 \mathrm{aA}$ \\
\hline Sorghum/ Pigeon Pea & $264,815 \mathrm{aA}$ & $342,500 \mathrm{aA}$ \\
\hline Single Sorghum & $271,907 \mathrm{aA}$ & $241,250 \mathrm{aA}$ \\
\hline
\end{tabular}

Mean values followed by the same lowercase letter in a column and uppercase letter on a row do not differ by Tukey's test (P<0.05) or by F-test $(\mathrm{P}<0.01)$. MSD: minimum significant difference by Tukey's test

for silage production, and obtained a stand of 127 thousand plants for forage sorghum compared to grain sorghum (167 thousand) and dual-purpose sorghum (143 thousand).

The data referring to fresh matter production in the sorghum, forage grasses, and pigeon pea, and to total fresh matter production in the treatments under evaluation, are shown in Table 4, where it can be seen that the monocropped sorghum (45.3 $\left.\mathrm{t} \mathrm{ha}^{-1}\right)$ afforded the greatest amount of plant biomass, while the sorghum intercropped with mombasa grass $\left(22.1 \mathrm{t} \mathrm{ha}^{-1}\right)$, and with mombasa grass and pigeon pea (23.6 $\left.\mathrm{t} \mathrm{ha}^{-1}\right)$ had the lowest productivity. However, when evaluating total fresh matter production, there was no effect between treatments.

For Rezende et al. (2011), there is controversy in the literature regarding data on fresh matter production in sorghum, as a large number of cultivars are studied

Table 4 - Mean values, Tukey's test and P-value (Anova) for fresh matter production in sorghum (FMPS), forage grass (FMPFG), and pigeon pea (FMPP), and total fresh matter production (FMPT), for treatments evaluated under an Integrated Farming Production System in a low-altitude region of Cerrado, at the time of the first cut. Selvíria MS

\begin{tabular}{|c|c|c|c|c|}
\hline \multirow{2}{*}{ Treatment (Trmt) } & FMPS & FMPFG & FMPP & FMPT \\
\hline & \multicolumn{4}{|c|}{$\mathrm{Kg} \mathrm{ha}^{-1}$} \\
\hline Sorghum/Marandu/Pigeon Pea & $39,803.7 \mathrm{ab}$ & $1,181.2 \mathrm{~b}$ & $3,133.3$ & $44,118.2$ \\
\hline Sorghum/Marandu & $35,981.3 \mathrm{~b}$ & $1,162.5 \mathrm{~b}$ & - & $37,143.8$ \\
\hline Sorghum/Mombasa/Pigeon Pea & $23,606.2 \mathrm{c}$ & $14,370.8 \mathrm{a}$ & $2,358.3$ & $40,335.3$ \\
\hline Sorghum/Mombasa & $22,148.3 \mathrm{c}$ & $19,062.5 \mathrm{a}$ & - & $41,210.8$ \\
\hline Sorghum/Pigeon Pea & $38,191.7 \mathrm{ab}$ & - & $2,600.0$ & $40,791.7$ \\
\hline Single Sorghum & $45,304.2 \mathrm{a}$ & - & - & $45,304.2$ \\
\hline $\mathrm{CV}(\%)$ & 29.4 & 42.2 & 53.3 & 20.7 \\
\hline \multicolumn{5}{|c|}{ Year $(Y)$} \\
\hline $2013 / 2014$ & $29,238.3 b$ & $11,118.7 \mathrm{a}$ & $788.9 \mathrm{~b}$ & $41,145.9 \mathrm{~b}$ \\
\hline $2014 / 2015$ & $39,106.8 \mathrm{a}$ & $6,769.8 \mathrm{~b}$ & $4,605.6 \mathrm{a}$ & $50,482.2 \mathrm{a}$ \\
\hline \multicolumn{5}{|c|}{ Anova (P-value) } \\
\hline Trmt & 0.0000 & 0.0002 & $0.5586^{\mathrm{ns}}$ & $0.2101^{\mathrm{ns}}$ \\
\hline $\mathrm{Y}$ & 0.0032 & 0.0072 & 0.0001 & 0.0021 \\
\hline Trmt x Y & $0.2406^{\mathrm{ns}}$ & 0.0079 & $0.2692^{\mathrm{ns}}$ & $0.3709^{\text {ns }}$ \\
\hline
\end{tabular}

Mean values followed by the same letter do not differ by Tukey's test at $5 \%$ significance $(\mathrm{P}<0.05)$ for treatment, or by F-test $(\mathrm{P}<0.01)$ for year 
(graniferous, forage and dual-purpose), generating values greater or smaller than those obtained in this experiment.

According to the data shown in this research, it can be seen that total fresh matter production was maximised $\left(8,877.5 \mathrm{~kg} \mathrm{ha}^{-1}\right)$ (Table 4), with sorghum dry matter during the second year of production maximised as a result. This increase in productivity can be explained by the better initial water supply (Figure 1), and the greater mean plant population (80 thousand plants $\mathrm{ha}^{-1}$ ) in the 2014/2015 crop (Table 1), compared to the previous year. These data are lower than those found by Botelho et al. (2011), who evaluated the agronomic characteristics of monocropped sorghum genotypes for silage production, and obtained a production of $51,850 \mathrm{~kg} \mathrm{ha}^{-1}$ at the time of the first cut in the Volumax cultivar sown at 12 seeds per metre.

Gomes et al. (2006), evaluating various sorghum genotypes, found the lowest $\left(17,637 \mathrm{~kg} \mathrm{ha}^{-1}\right)$ and highest $\left(57,126 \mathrm{~kg} \mathrm{ha}^{-1}\right)$ yield in the BRS 701 and IPA467-4-2 cultivars respectively. For the Volumax cultivar, the authors obtained a fresh matter production of $22,672 \mathrm{~kg} \mathrm{ha}^{-1}$, a value close to those found in this study for sorghum intercropped with mombasa grass and sorghum intercropped with mombasa grass and pigeon pea. Whereas Rabelo et al. (2012), evaluating sowing strategies and fertilisation with NPK in sorghum on the agronomic attributes of the crop, found a fresh matter production of $27,280 \mathrm{~kg} \mathrm{ha}^{-1}$ at a spacing of $0.80 \mathrm{~m}$ between rows, which can be attributed to less intraspecific competition at this spacing.

At high plant densities, intraspecific competition in the sorghum was confirmed by Lopes et al. (2005), who found higher grain production per plant at the lowest density of 100 thousand plants $\mathrm{ha}^{-1}$, compared to the highest density of 220 thousand plants $\mathrm{ha}^{-1}$ at the two spacings under study, 0.5 and $0.8 \mathrm{~m}$. These same authors found that fresh matter production in the forage sorghum increased linearly as a function of fertilisation, with increments of $417 \mathrm{~kg} \mathrm{ha}^{-1}$ being seen for each unit increase in NPK.

There was no significant difference $(\mathrm{P}>0.05)$ in fresh matter (Table 4) or total dry matter (Table 5) production per intercropped system between the treatments under evaluation; however, there was a significant effect $(\mathrm{P}<0.01)$ when comparing the DMPT for each year, with an increase in production of $21.0 \%$ in the second year compared to year one (Table 5).

According to Borghi et al. (2004), fertilising maize by area and plant, population density, and plant development, as a function of the system of soil management, generally, in the absence of adverse conditions, results in the formation of larger and consequently heavier ears due to less competition between

Table 5 - Dry matter production in sorghum (DMPS), forage grass (DMPFG), and pigeon pea (DMPP), and total dry matter production (DMPT), under an Integrated Farming Production System in a low-altitude region of Cerrado, at the time of the first cut. Selvíria MS

\begin{tabular}{|c|c|c|c|c|}
\hline \multirow{2}{*}{ Treatment (Trmt) } & DMPS & DMPFG & DMPP & DMPT \\
\hline & \multicolumn{4}{|c|}{$\mathrm{Kg} \mathrm{ha}^{-1}$} \\
\hline Sorghum/Marandu/Pigeon Pea & $16,123.7 \mathrm{a}$ & $415.1 \mathrm{~b}$ & $1,031.1$ & $17,569.9$ \\
\hline Sorghum/Marandu & $15,073.3 \mathrm{a}$ & $457.0 \mathrm{~b}$ & - & $15,530.3$ \\
\hline $\begin{array}{c}\text { Sorghum/Mombasa/Pigeon } \\
\text { Pea }\end{array}$ & $8,793.0 \mathrm{~b}$ & $4,979.4 \mathrm{a}$ & 817.2 & $14,589.6$ \\
\hline Sorghum/Mombasa & $8,415.3 \mathrm{~b}$ & $6,062.6 \mathrm{a}$ & - & $14,477.9$ \\
\hline Sorghum/Pigeon Pea & $15,249.4 \mathrm{a}$ & - & 864.7 & $16,114.1$ \\
\hline Single Sorghum & $17,346.7 \mathrm{a}$ & - & - & $17,346.7$ \\
\hline $\mathrm{CV}(\%)$ & 20.3 & 43.8 & 49.8 & 23.4 \\
\hline \multicolumn{5}{|c|}{$\operatorname{Year}(\mathrm{Y})$} \\
\hline $2013 / 2014$ & $11,646.9 \mathrm{~b}$ & $4,040.8 \mathrm{a}$ & $374.2 \mathrm{~b}$ & $16,061.9 \mathrm{~b}$ \\
\hline $2014 / 2015$ & $15,353.6 \mathrm{a}$ & $1,916.3 \mathrm{~b}$ & $1,534.4 \mathrm{a}$ & $18,804.3 \mathrm{a}$ \\
\hline \multicolumn{5}{|c|}{ Anova (P-value) } \\
\hline Trmt & 0.0000 & 0.0000 & $0.5812^{\mathrm{ns}}$ & $0.2345^{\mathrm{ns}}$ \\
\hline $\mathrm{Y}$ & 0.0055 & 0.0006 & 0.0001 & 0.0140 \\
\hline Trmt x Y & $0.2257^{\mathrm{ns}}$ & 0.0009 & $0.2715^{\mathrm{ns}}$ & $0.3381^{\mathrm{ns}}$ \\
\hline
\end{tabular}

Mean values followed by the same letter in a column do not differ by Tukey's test at $5 \%$ significance $(\mathrm{P}<0.05)$ for treatment, or by F-test $(\mathrm{P}<0.01)$ for year 
species and the better spatial arrangement of the plants together with proper fertilisation. This is due to the greater physiological capacity of the plants, a result of the greater water and nutrient absorption capacity of the intercropped systems; similar results to those of the sorghum intercrops evaluated here.

Over two years in Selvíria MS, Carvalho et al. (2004) obtained a mean value for dry matter weight of $2,478 \mathrm{~kg} \mathrm{ha}^{-1}$ in pigeon pea sown in November and managed 60 days after emergence, albeit as a single crop. This was higher than the value found in this study (mean of $904.3 \mathrm{~kg} \mathrm{ha}^{-1}$ ) (Table 5), intercropped with sorghum, and with Mombasa and Marandu grass.

When developing a study to evaluate fresh and dry matter production in cover plants under three crop successions and two types of soil preparation in a typical dystrophic Red Latosol, Suzuki and Alves (2006) found that pigeon pea afforded the lowest dry matter production $\left(6,465 \mathrm{~kg} \mathrm{ha}^{-1}\right)$, a behaviour that is consistent with that seen by Almeida (2001). This author states that low dry matter production in the pigeon pea may be associated with its slow development, which enabled weeds to emerge and compete with the pigeon pea for water, light and nutrients. This observation is also valid for the conditions of the present experiment, where the intercropped systems have the same basis for competition as that provided by the weeds, not least because the grasses tested here have $\mathrm{C} 4$ metabolism, with more vigorous growth than the pigeon pea with $\mathrm{C} 3$ metabolism.

Based on the fresh matter of the sorghum, significant differences between the treatments under study were found regarding the percentage of stems and leaves, with no significant difference for the percentage of panicles (Table 6). The highest and lowest percentage of stems was 64.5 and $54.8 \%$ respectively, for single sorghum and sorghum intercropped with mombasa grass; however, taller sorghum hybrids may have a greater percentage of stems, which can compromise the nutritional quality of the silage produced from these hybrids (ZAGO, 1997).

The results of this research are close to those found by Botelho et al. (2011), who evaluated sorghum genotypes for silage production and found mean values for the percentage of stems ranging from 55.1 to $68.0 \%$, while Oliveira et al. (2005) found percentages of 63.6 to $85.8 \%$ in sorghum hybrids in a typical clayey dystrophic Red Latosol, similar to that of the present study.

The percentage of leaves in the sorghum plants varied between 25.0 and $29.7 \%$ (Table 6), with the intercropped sorghum and mombasa grass having the highest percentage $(29.7 \%)$. The lowest percentage

Table 6 - Mean values, Tukey's test and P-value (Anova) for the percentage of stem, leaf and panicle fractions in sorghum intercropped with marandu grass, mombasa grass and/or pigeon pea based on the fresh matter, under an Integrated Farming Production System in a low-altitude region of Cerrado, at the time of the first cut. Selvíria MS

\begin{tabular}{|c|c|c|c|}
\hline \multirow{2}{*}{ Treatment (Trmt) } & Stem & Leaves & Panicle \\
\hline & \multicolumn{3}{|c|}{$\%$} \\
\hline Sorghum/Marandu/Pigeon Pea & $60.6 \mathrm{ab}$ & $27.2 \mathrm{ab}$ & 12.2 \\
\hline Sorghum/Marandu & $63.5 \mathrm{a}$ & $25.0 \mathrm{~b}$ & 11.5 \\
\hline Sorghum/Mombasa/Pigeon Pea & $58.8 \mathrm{ab}$ & $29.5 \mathrm{ab}$ & 11.7 \\
\hline Sorghum/Mombasa & $54.8 \mathrm{~b}$ & $29.7 \mathrm{a}$ & 15.5 \\
\hline Sorghum/Pigeon Pea & $62.0 \mathrm{ab}$ & $26.8 \mathrm{ab}$ & 11.1 \\
\hline Single Sorghum & $64.5 \mathrm{a}$ & $25.6 \mathrm{~b}$ & 9.9 \\
\hline $\mathrm{CV}(\%)$ & 6.6 & 14.3 & 19.8 \\
\hline \multicolumn{4}{|c|}{ Year $(\mathrm{Y})$} \\
\hline 1 & $59.3 \mathrm{~b}$ & 26.9 & $13.7 \mathrm{a}$ \\
\hline 2 & $62.1 \mathrm{a}$ & 27.7 & $10.2 \mathrm{~b}$ \\
\hline \multicolumn{4}{|c|}{ Anova (P-value) } \\
\hline Trmt & 0.0114 & 0.0057 & $0.4230^{\text {ns }}$ \\
\hline $\mathrm{Y}$ & 0.0441 & $0.9097^{\mathrm{ns}}$ & 0.0008 \\
\hline Trmt x Y & $0.2465^{\mathrm{ns}}$ & $0.4978^{\mathrm{ns}}$ & $0.1074^{\mathrm{ns}}$ \\
\hline
\end{tabular}

Mean values followed by the same letter do not differ by Tukey's test at $5 \%$ significance $(\mathrm{P}<0.05)$ for treatment, or by F-test $(\mathrm{P}<0.01)$ for year 
of leaves was found in the sorghum intercropped with marandu grass $(25.0 \%)$, and in the single sorghum (25.6\%), showing no significant difference between each other.

When the percentage of leaves is analysed between years, no significant difference is seen. Gomes et al. (2006), evaluating sorghum genotypes (BR100, Volumax, SHS 500, MASSA 03, BRS 701, 0698005, AG 2005E, BRS 506, 0698007, BR601 and IPA467-4-2), determined a higher percentage of leaves $(23.0 \%)$ in the Volumax cultivar, with a value below those shown in this research.

Among the various parts of the sorghum, the most important is the panicle, where the greatest nutritional value of the plant is concentrated, given the greater digestibility coefficient of the grain in relation to the stalk and leaves. For the sorghum genotypes BR100, Volumax, SHS 500, MASSA 03, BRS 701, 0698005, AG 2005E, BRS 506, 0698007, BR601 and IPA467-4-2, Gomes et al. (2006) found a mean CP content of $9.7 \%$ in the panicle, a higher value than found in the leaves $(6.3 \%)$ or stalk $(1.7 \%)$.

The percentage of panicles found in the treatments varied from 9.9 to $12.2 \%$ (Table 6). Von Pinho et al. (2007) compared sorghum productivity as a function of sowing time, and obtained $17.7 \%$ of panicles in the forage genotype, a value higher than those found in this work. It is worth pointing out the greater percentage of panicles in the intercropped systems in relation to the single sorghum, even if not significant ( $\mathrm{P}>0.05)$. In general, these percentages were higher for the cropping systems under evaluation compared to the values obtained by Chiesa et al. (2008), who evaluated the percentage of panicles in sorghum fresh matter, and found values of 5.0, 2.2 and $2.0 \%$ respectively, for the AG 2005E, AG 60298 and BR 101 genotypes.

\section{CONCLUSIONS}

1. Plant height and stem diameter in the sorghum, as well as stand, were influenced by the prevailing climate conditions during each agricultural year;

2. Fresh matter production in the sorghum was influenced by the cropping system, however, there was no difference in total fresh or dry matter production in the intercropped systems;

3. Sorghum intercropped with mombasa grass gave a higher percentage of panicles in the fresh matter, as well as a better ratio of plant components (stem, leaves and panicle).

\section{ACKNOWLEDGEMENTS}

The authors wish to thank FAPESP (Process no 2013/21339-6 and 2015/06685-0) and CNPq for the scientific initiation and postgraduate scholarships to carry out this project.

\section{REFERENCES}

ALBUQUERQUE, C. J. B. et al. Espaçamento entre fileiras e densidade de semeadura do sorgo forrageiro para a região norte de minas gerais. Ciência e Agrotecnologia, v. 35, n. 1, p. 494-501, 2011.

ALMEIDA, V. P. Sucessão de culturas em preparo convencional e plantio direto em Latossolo Vermelho sob vegetação de cerrado. 2001. 71 f. Dissertação (Mestrado em Agronomia - Sistemas de Produção) - Faculdade de Engenharia, Universidade Estadual Paulista, Ilha Solteira, 2001.

BENÍCIO, L. P. F. et al. Produção de Megathyrsus maximum consorciado com sorgo sob diferentes fontes de fósforo. Tecnologia \& Ciência Agropecuária, v. 5, n. 1, p. 55-60, 2011.

BORGHI, E. et al. Adubação por área e por planta, densidade populacional e desenvolvimento do milho em função do sistema de manejo do solo. Acta Scientiarum: Agronomy, v. 26, n. 1, p. $337-345,2004$

BOTELHO, P. R. F. et al. Avaliação de genótipos de sorgo em primeiro corte e rebrota para produção de silagem. Revista Brasileira de Milho e Sorgo, v. 9, n. 1, 2011. Disponível em: http://rbms.cnpms.embrapa.br/index.php/ojs/article/ view/309/422. Acesso em: 25 mar. 2015.

CARVALHO, M. A. C. et al. Produtividade de arroz no sistema integração lavoura-pecuária com o uso de doses reduzidas de herbicida. Bragantia, v. 70, n. 1, p. 33-39, 2011.

CARVALHO, M. A. C. et al. Produtividade do milho em sucessão a adubos verdes no sistema plantio direto e convencional. Pesquisa Agropecuária Brasileira, v. 39, n. 1, p. 47-53, 2004.

CARVALHO, P. C. F. et al. Managing grazing animals to achieve nutrient cycling and soil improvement in no-till integrated systems. Nutrient Cycling in Agroecosystems, v. 88, n. 1, p. 259-273, 2010.

CHIESA, E. D. et al. Aspectos agronômicos de híbridos de sorgo (Sorghum bicolor, L. Moench) no desempenho e economicidade de novilhos confinados. Revista Acta Scientiarum: Animal Sciences, v. 30, n. 1, p. 67-73, 2008.

EMPRESA BRASILEIRA DE PESQUISA AGROPECUÁRIA. Centro Nacional de Pesquisa dos Solos. Sistema brasileiro de classificação de solos. Rio de Janeiro: Embrapa/CNPS, 2013. $353 \mathrm{p}$.

FERNANDES, P. G. et al. Influência do espaçamento e da população de plantas de sorgo sacarino em diferentes épocas semeadura. Ciência Rural, v. 44, n. 6, p. 975-981, 2014. 
FERREIRA, D. F. Sisvar: a computer statistical analysis system. Ciência e Agrotecnologia, v. 35, n. 1, p. 1039-1042, 2011.

FOLONI, J. S. S. et al. Rebrota de soqueiras de sorgo em função da altura de corte e da adubação nitrogenada. Revista Ceres, v. 55, n. 2, p. 102-108. 2008. Disponível em: http:// www.redalyc.org/articulo.oa?id=305226700009. Acesso em: 10 fev. 2015.

GOMES, S. O. et al. Comportamento agronômico e composição químico-bromatológico de cultivares de sorgo forrageiro no Estado do Ceará. Revista Ciência Agronômica, v. 37, n. 2, p. 221-227, 2006

KLUTHCOUSKI, J.; AIDAR, H. Implantação, condução e resultados obtidos com o Sistema Santa Fé. In: KLUTHCOUSKI, J.; STONE, L. F.; AIDAR, H. (ed.). Integração lavourapecuária. Santo Antônio de Goiás: Embrapa Arroz e Feijão, 2003. p. 407-442.

LANZANOVA, M. E. et al. Atributos físicos do solo em sistema de integração lavoura-pecuária sob plantio direto. Revista Brasileira de Ciência do Solo, v. 31, p. 1131-1140, 2007.

LOPES, S. J. et al. Tamanho de parcela para produtividade de grãos de sorgo granífero em diferentes densidades de plantas. Pesquisa Agropecuária Brasileira, v. 40, n. 6, p. 525-530, 2005.

MAY, A. et al. Influência do arranjo de plantas no desempenho produtivo de sorgo sacarino (Sorghum bicolor (L.) Moench), em Sete Lagoas-MG. In: CONGRESSO NACIONAL DE MILHO E SORGO, 29., 2012, Águas de Lindóia. Anais [...]. Águas de Lindóia: ABMS, 2012a. p. 2382-2389. 1 CDROM.

MAY, A. et al. Manejo e tratos culturais. Sistema Embrapa de produção agroindustrial de sorgo sacarino para bioetanol: Sistema BRS1G-Tecnologia Qualidade Embrapa. Sete Lagoas: Embrapa Milho e Sorgo, 2012b. p. 22-31.
MIRANDA, N. O. et al. Sorgo forrageiro em sucessão a adubos verdes na região de Mossoró, RN. Revista Brasileira de Ciências Agrárias, v. 5, n. 2, p. 202-206, 2010.

OLIVEIRA, R. P. et al. Características agronômicas de cultivares de sorgo (Sorghum bicolor (L.) Moench) sob três doses de nitrogênio. Pesquisa Agropecuária Tropical, v. 35, n. 1, p. 45-53, 2005.

RABELO, F. H. S. et al. Parâmetros agronômicos do sorgo em razão de estratégias de semeadura e adubação. Revista Brasileira de Tecnologia Aplicada nas Ciências Agrárias, v. 5, n. 1, p. 47-66, 2012.

RAIJ, B. VAN. et al. Análise química para avaliação da fertilidade de solos tropicais. Campinas: Instituto Agronômico, 2001. 284 p.

REZENDE, G. M. et al. Características agronômicas de cinco genótipos de sorgo (Sorghum bicolor (L.) MOENCH), cultivados no inverno, para a produção de silagem. Revista Brasileira de Milho e Sorgo, v. 10, n. 2, p. 171-179, 2011. Disponível em: http://rbms.cnpms.embrapa.br/index.php/ojs/ article/view/316/454. Acesso em: 25 mar. 2015.

SUZUKI, L. E. A. S.; ALVES, M. C. Fitomassa de plantas de cobertura em diferentes sucessões de culturas e sistemas de cultivo. Bragantia, v. 65, n. 1, p. 121-127, 2006.

VON PINHO, R. G. et al. Influência da altura de corte das plantas nas características agronômicas e valor nutritivo das silagens de milho e de diferentes tipos de sorgo. Revista Brasileira de Milho e Sorgo, v. 5, n. 2, p. 266- 279, 2006.

VON PINHO, R. G. et al. Produtividade e qualidade da silagem de milho e sorgo em função da época de semeadura. Bragantia, v. 66, n. 2, p. 235-245, 2007.

ZAGO, C. P. Utilização do sorgo na alimentação de ruminantes: manejo cultural do sorgo para forragem. Sete Lagoas: Embrapa-CNPMS, 1997. p. 9-26. (Embrapa-CNPMS. Circular Técnica, 17). 